\title{
Communication
}

\section{Concentrations of Tetrodotoxin (TTX) and Its Analogue 4,9-Anhydro TTX in Different Tissues of the Silver-Cheeked Pufferfish (Lagocephalus sceleratus, Gmelin, 1789) Caught in the South-Eastern Mediterranean Sea, Lebanon}

\author{
Abed El Rahman Hassoun ${ }^{1, *} \mathbb{0}$, Ivana Ujević ${ }^{2}{ }^{\infty}$, Sharif Jemaa ${ }^{1}$, Romana Roje-Busatto ${ }^{2}$, Céline Mahfouz ${ }^{1}$, \\ Milad Fakhri ${ }^{1}$ and Nikša Nazlić ${ }^{2}$ \\ 1 National Council for Scientific Research, National Center for Marine Sciences, Batroun P.O. Box 534, Lebanon; \\ sharif.jemaa@cnrs.edu.lb (S.J.); celine.mahfouz@cnrs.edu.lb (C.M.); milosman@cnrs.edu.lb (M.F.) \\ 2 Laboratory of Plankton and Shellfish Toxicity, Institute of Oceanography and Fisheries, Šetalište Ivana \\ Meštrovića 63, 21000 Split, Croatia; ujevic@izor.hr (I.U.); rroje@izor.hr (R.R.-B.); nazlic@izor.hr (N.N.) \\ * Correspondence: abedhassoun@cnrs.edu.lb; Tel.: +961-31-17537
}

Citation: Hassoun, A.E.R.; Ujević, I.; Jemaa, S.; Roje-Busatto, R.; Mahfouz,

C.; Fakhri, M.; Nazlić, N.

Concentrations of Tetrodotoxin (TTX) and Its Analogue 4,9-Anhydro TTX in Different Tissues of the Silver-Cheeked Pufferfish (Lagocephalus sceleratus, Gmelin, 1789) Caught in the South-Eastern Mediterranean Sea, Lebanon. Toxins 2022, 14, 123. https://doi.org/ $10.3390 /$ toxins 14020123

Received: 22 November 2021 Accepted: 20 December 2021 Published: 8 February 2022

Publisher's Note: MDPI stays neutral with regard to jurisdictional claims in published maps and institutional affiliations.

Copyright: (C) 2022 by the authors. Licensee MDPI, Basel, Switzerland. This article is an open access article distributed under the terms and conditions of the Creative Commons Attribution (CC BY) license (https:// creativecommons.org/licenses/by/ $4.0 /$ )

\begin{abstract}
Pufferfishes are among the best-known marine organisms that accumulate marine biotoxins such as Tetrodotoxin (TTX). In the Mediterranean Sea, the silver-cheeked toadfish Lagocephalus sceleratus is the most reported TTX-bearer, causing many fatal and non-fatal cases. In Lebanon, no previous studies have measured TTX levels although the possibility of TTX-poisoning is high since L. sceleratus is caught in different sizes and can be mistaken with other small fishes. Hence, this study reports TTX and its analogue 4,9-anhydro TTX in L. sceleratus collected from Lebanese waters in the Eastern Mediterranean Sea. The results show that TTX concentrations in fish tissues varied between 0.10 and $252.97 \mu \mathrm{g} / \mathrm{g}$, while those of 4,9-anhydro TTX oscillated between 0.01 and $43.01 \mu \mathrm{g} / \mathrm{g}$. Internal organs of L. sceleratus were the most toxic parts of its body, with the highest TTX levels found in gonads (mainly ovaries) and liver, followed by the muscles and skin with concentrations always exceeding the safety level. Toxicity fluctuations of L. sceleratus, its expansion, ecological and economic effects were also elucidated. Based on the present findings, it has been confirmed that L. sceleratus constitutes a health, ecological and economic risks, and therefore its trade in seafood markets should be banned to avoid any potential intoxication.
\end{abstract}

Keywords: marine toxins; seafood security; pufferfish; invasive species; Mediterranean Sea; Lebanon

Key Contribution: This article presents the first report of TTX concentrations in any marine organisms from the Lebanese marine environment. It will certainly support the authors to continue this monitoring effort and in shaping better legislations that would prohibit TTX-contaminated seafood from the Lebanese seafood market to avoid any potential intoxication.

\section{Introduction}

Marine biotoxins are naturally existing chemicals produced by toxic algae that can accumulate in marine biota [1]. However, some biotoxins are thought to be produced primarily by marine bacteria. These toxins may bioaccumulate through the food chain or in combination with parasitism or symbiosis (a part of the animal's natural microbiome), thus intoxicating detritus feeders, small carnivores, omnivores/scavengers, and organisms higher up the food chain [2]. This is the case of Tetrodotoxin (TTX), a non-protein, weakly basic organic, and low molecular weight compound that is soluble in water and acidic environments, colorless, odorless, tasteless, and heat resistant [3-5]. Approximately 25 naturally occurring analogues of TTX have been detected and many of these have also been shown to have toxicity potential [6]. TTX is as much as 1200 times stronger than the well-known poison cyanide [6]. It acts by binding and thus blocking the voltage-gated 
sodium channels of the musculatory and nervous system [7,8]. Although TTX has been detected in a variety of marine animals [9], 93.7\% of intoxications are due to fishes of the order Tetraodontiformes, namely pufferfish, that are the most-known fish genus containing this potent neurotoxin [10]. In fact, pufferfish might be attracted by TTX and select TTXbearing organisms as food, resulting in accumulation of TTX as a possible biological defense agent [2]. Due to the presence of high TTX levels in its various tissues, Lagocephalus sceleratus (Gmelin, 1789) is considered one of the most poisonous fish in the world. This explains the high number of studies related to TTX occurrence in the Mediterranean pufferfish, particularly in this fish species $[4,5,11-15]$.

\subsection{Lagocephalus sceleratus (Gmelin, 1789)}

The marine fish species Lagocephalus sceleratus (Gmelin, 1789), also known as the silver-cheeked toadfish, belongs to Tetraodontidae family that was introduced in the Mediterranean via the "Lessepsian migration". This latter term was invented to characterize the unidirectional migration of the Indo-Pacific/Red Sea marine species that have crossed the Suez Canal since 1869 towards the Eastern Mediterranean Sea [16], where they have established successful settlements, thus becoming a major component of the Mediterranean Sea marine biota $[12,17,18]$. More than 300 Lessepsian species from various taxa were brought to the Mediterranean Sea and L. sceleratus is considered among the most dangerous in terms of toxicological, ecological and economic impacts $[7,11,16,19]$. L. sceleratus has been included in the blacklist as one of the 18 worst invader fish species by the IUCN [20]. This species is mostly found between 18 and $100 \mathrm{~m}$ depth [21] and does not have predators in the Mediterranean Sea [22]. In addition, it can inflate itself with water and air as a defense mechanism which makes it more difficult to be swallowed by potential predators [23], which additionally explains the exponential increase in its number $[7,22]$. Based on the available literature, the first record of L. sceleratus in the Mediterranean Sea dates back to February 2003 in Gökova Bay, located in the Southern Aegean Sea, Turkey [24]. However, L. sceleratus was reported for the first time in Lebanese waters during 1977 [25], showing that this species has been expanding in the Levantine Sub-basin of the Mediterranean Sea long before the first observations became available in the literature in 2003 and subsequently in 2004 for the South-Eastern Levantine Sea [26,27]. Afterwards, the expansion of this species was recorded in various Mediterranean sub-basins, confirming its ability to adapt to different environments $[7,28]$.

\subsection{TTX Intoxication}

Food poisoning related to the consumption of TTX-bearing organisms, such as pufferfish, occurs when the flesh and/or organs of the fish are improperly prepared and eaten. There are no known antidotes or antitoxins to treat TTX-intoxicated patients $[5,29]$. The number of TTX intoxications has been increasing worldwide with reports from Australia, Bangladesh, Brazil, China, India, Japan, Madagascar, Reunion Island, Spain, Taiwan, Thailand, the United States, and Tanzania [2,8,30-40]. Compared to the rest of the world, around $38 \%$ of TTX-related fatalities occurred in Europe and the Middle Eastern/African countries (21.4 and 16.7\%, respectively) [10]. In the Mediterranean Sea region, due to its 'famous' toxicity, the human consumption of L. sceleratus is not common. In addition, according to the European legislative requirements [41,42], poisonous fish of the family Tetraodontidae and derived products must not be placed on the market. However, accidental capture and consumption of this species has been documented in many parts of the Eastern Mediterranean Sea $[11,29,43]$. Depending on the amount of the ingested TTX, symptoms might initiate with oral paresthesia that spreads to the extremities and body with disturbance, dizziness, headache, and diaphoresis, and can impact the gastrointestinal and/or nervous and mobility systems causing paralysis, muscle coordination disorders, respiratory depression, circulatory failure, and nausea, and eventually death [11,29,44-49]. Symptoms usually appear within 10 to $45 \mathrm{~min}$, and exceptionally 3 to $6 \mathrm{~h}$ after exposure [11]. 
All the above-mentioned serious health issues, which may result from accidental consumption of TTX-bearing organisms such as L. sceleratus, show that TTXs can now be considered among the most threatening emerging toxins to food security in Europe. Nevertheless, maximum permitted limits have not yet been set, and no specific monitoring plans have been adopted so far. This emphasizes the importance of measuring its concentrations in species from around the Mediterranean, such as the Lebanese waters, to test its toxicity. A TTX-poisoning case was documented in Lebanon, with serious symptoms that occurred within 3 to $4 \mathrm{~h}$ after the consumption of L. sceleratus gonads [29], although there are regulations that prohibit the selling of pufferfish in Lebanese seafood markets (No. 676/1 of 27 July 2011). Despite this incident, there is no TTX reporting yet to highlight the toxicity of pufferfish based on scientific data collected from local species. Therefore, this study constitutes the first report of TTX concentrations in various tissues of L. sceleratus collected from the Lebanese waters in the South-Eastern Mediterranean Sea. The presented results provide information on this species in order to raise the public awareness of its toxicity.

\section{Results}

The L. sceleratus specimens were sampled at the same location, and details of their morphological and sex analysis, as well as the range of TTX and its analogue concentrations in their different organs and tissues, are shown in Table 1.

Table 1. Morphological details of L. sceleratus and TTX and 4,9-anhydro TTX concentration ranges in organs (gonads, liver, muscle, and skin) of each fish specimen $(\mu \mathrm{g} / \mathrm{g})$. Total Length (TL), Total Weight (TW), Liver Weight (LW) and Gonads Weight (GW).

\begin{tabular}{|c|c|c|c|c|c|c|c|c|c|c|c|c|}
\hline \multirow{2}{*}{$\begin{array}{l}\text { Fish } \\
\text { Code }\end{array}$} & \multirow{2}{*}{$\begin{array}{l}\text { TL } \\
(\mathrm{cm})\end{array}$} & \multirow{2}{*}{$\begin{array}{c}\text { TW } \\
(\mathrm{g})\end{array}$} & \multirow{2}{*}{ Sex } & \multirow{2}{*}{ Maturity } & \multirow{2}{*}{$\begin{array}{l}\text { LW } \\
(\mathrm{g})\end{array}$} & \multirow{2}{*}{$\begin{array}{c}\mathrm{GW} \\
(\mathrm{g})\end{array}$} & \multirow{2}{*}{$\begin{array}{l}\text { Range of } \\
\text { TTX }(\mu \mathrm{g} / \mathrm{g})\end{array}$} & \multirow{2}{*}{$\begin{array}{c}\text { Range of } \\
\text { 4,9-Anhydro }(\mu \mathrm{g} / \mathrm{kg})\end{array}$} & \multicolumn{4}{|c|}{ TTX/4,9-Anhydro $(\mu \mathrm{g} / \mathrm{g})$} \\
\hline & & & & & & & & & Muscle & Skin & Liver & Gonads \\
\hline Fish 1 & 58.9 & 2608.5 & Female & 4 & 245 & 50.1 & $0.60-252.97$ & $0.08-43.01$ & $\begin{array}{c}0.60 / 7.5 \\
\times 10^{-5}\end{array}$ & $\begin{array}{l}0.71 / 11.3 \\
\times 10^{-4}\end{array}$ & $46.67 / 0.013$ & $252.97 / 0.043$ \\
\hline Fish 2 & 48.3 & 1238.8 & Male & 2 & 58.7 & 5.4 & $0.17-12.96$ & $0.03-2.65$ & $\begin{array}{c}0.26 / 3.2 \\
\times 10^{-5}\end{array}$ & $\begin{array}{c}0.17 / 2.8 \\
\times 10^{-5}\end{array}$ & $12.96 / 0.0026$ & $\begin{array}{c}0.26 / 5.8 \times \\
10^{-5}\end{array}$ \\
\hline Fish 3 & 19 & 82.2 & Female & 2 & 4 & 0.8 & $0.10-2.71$ & $0.03-0.77$ & $\begin{array}{c}0.10 / 1.2 \\
\times 10^{-5}\end{array}$ & $\begin{array}{c}0.15 / 2.7 \\
\times 10^{-5}\end{array}$ & $\begin{array}{c}1.37 / 6 \times \\
10^{-4}\end{array}$ & $\begin{array}{c}2.71 / 7 \\
10^{-4}\end{array}$ \\
\hline
\end{tabular}

\subsection{TTX Concentrations}

The results demonstrate that concentrations of TTX and its analogue 4,9-anhydro TTX follow the same pattern in all the fish specimens and their individual organs (Table 1; Figures 1 and 2). The highest TTX and 4,9-anhydro TTX concentrations were detected in Fish 1, the largest and the most mature fish examined (252.97 and $43.01 \mu \mathrm{g} / \mathrm{g}$ for TTX and 4,9-anhydro TTX, respectively); whereas the lowest concentrations were found in Fish 3, the smallest one $(0.10$ and $0.03 \mu \mathrm{g} / \mathrm{g}$ for TTX and 4,9-anhydro TTX, respectively; Table 1$)$.

Based on the results, it is clear that TTX and 4,9-anhydro TTX concentrations may vary considerably with respect to different organs of L. sceleratus, exhibiting the highest concentrations in gonads (in ovaries), then in liver, followed by the muscles and skin (Figures 1 and 2, Table 1), while it is higher in the liver in testis (Table 1). 


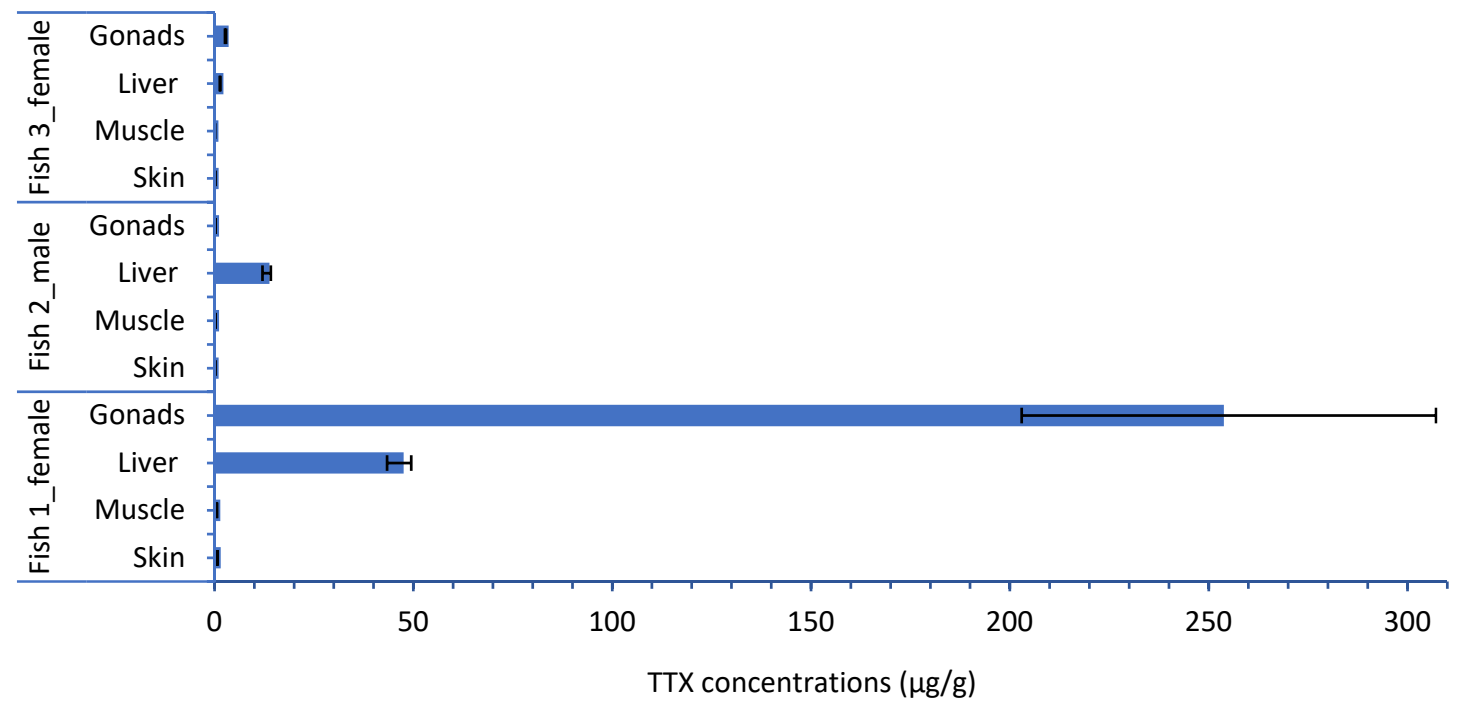

Figure 1. TTX concentrations ( $\mu \mathrm{g} / \mathrm{g}$ ) in organs (gonads, liver, muscle and skin) of each L. sceleratus specimen (bars represent minimum and maximum of TTX concentrations, $n=5$ ).

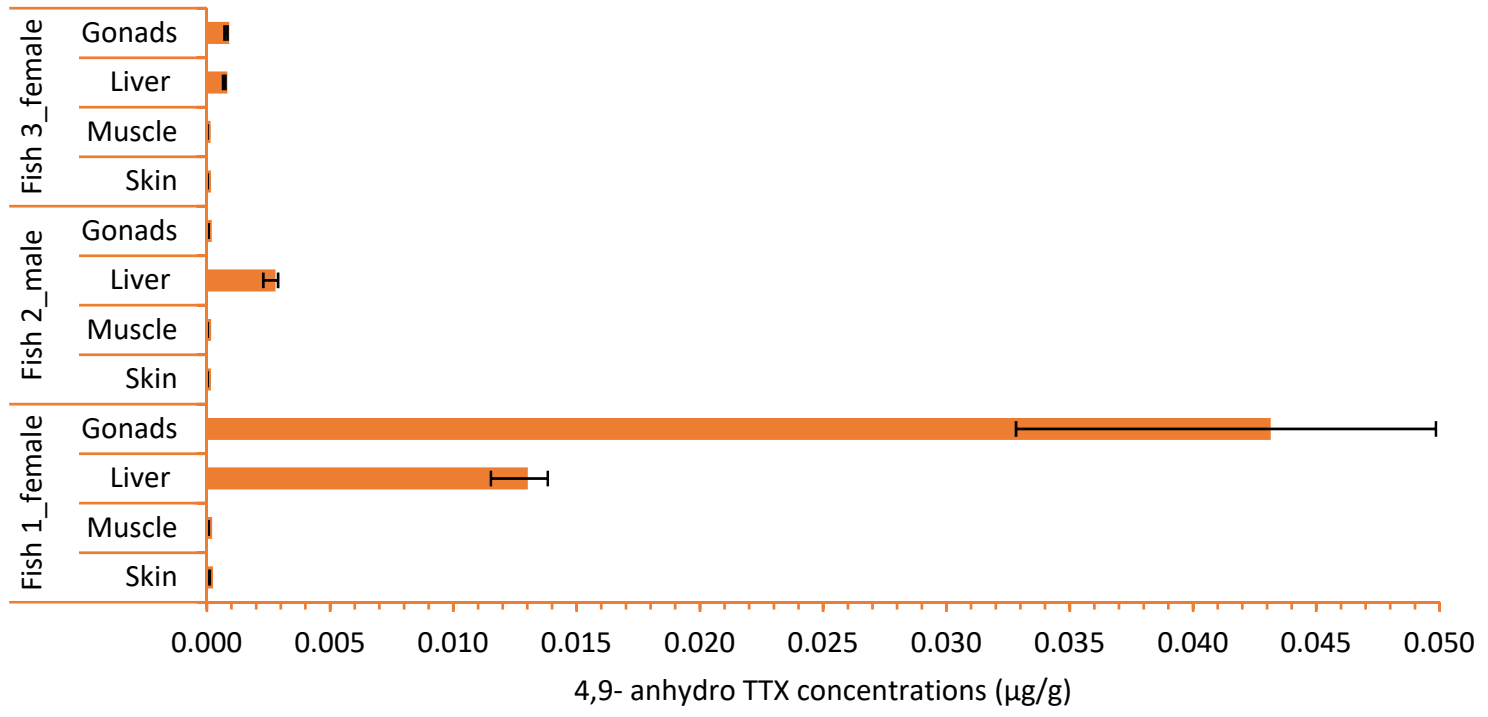

Figure 2. 4,9-anhydro TTX concentrations ( $\mu \mathrm{g} / \mathrm{g}$ ) in organs (gonads, liver, muscle and skin) of each L. sceleratus specimen (bars represent minimum and maximum of 4,9-anhydro TTX concentrations, $n=5)$.

\subsection{TTX Toxicity}

All measured TTX and 4,9-anhydro TTX concentrations in all analyzed fish organs exceeded the safety level set by the European Food Safety Authority (EFSA) for toxic effects in humans, which is $0.044 \mu \mathrm{g} / \mathrm{g}$ for TTX and its analogues, based on the consumption of $400 \mathrm{~g}$ of marine bivalve and gastropods/shellfish meat [6]. For example, the muscle of the smallest fish (Fish 3) presented a concentration of TTX and 4,9-anhydro TTX combined $(0.103 \mu \mathrm{g} / \mathrm{g})$ more than twofold higher than the determined safety level (Figure 3).

Only the skin and muscle of the smallest Fish 3 showed combined TTX (TTX and 4,9anhydro TTX) concentrations lower than the Minimum Acute Dose (MAD = $0.2 \mu \mathrm{g} / \mathrm{g}$ ) [11]; whereas livers of the largest and medium-sized fish (Fish 1 and 2, respectively) contained concentrations greater than the LDL0. Female gonads (ovaries) of both Fish 1 and Fish 3 comprised concentrations above the Lowest Lethal Dose (LDL0 $=2 \mu \mathrm{g} / \mathrm{g}$; Figure 3) [11]. 


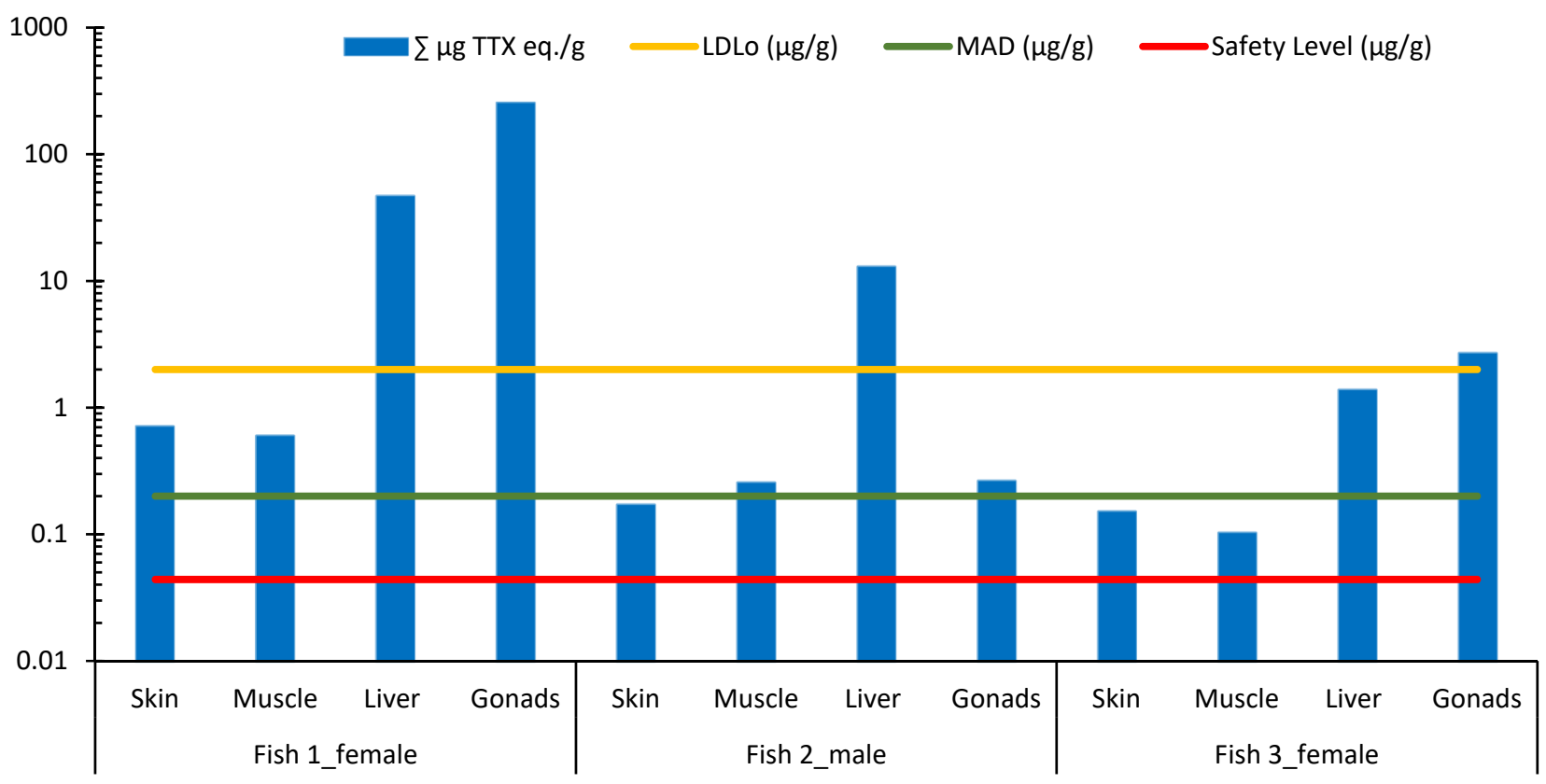

Figure 3. Logarithmic presentation of combined TTX and 4,9-anhydro TTX concentrations ( $\mu \mathrm{g} / \mathrm{g})$ in each organ of $L$. sceleratus specimens with visualization of the Lowest Lethal Dose $\left(\mathrm{LDL}_{0}\right)$, the Minimum Acute Dose (MAD), and the Safety level (according to [6]).

\section{Discussion}

\subsection{TTX Toxicity in Lebanon, the South-Eastern Mediterranean Sea}

Despite the fact that pufferfish species, in general, are not consumed in the Mediterranean region, about 156 intoxication cases have been recorded in various Mediterranean countries, and have mainly been attributed to L. sceleratus, as shown in a detailed overview by Guardone et al. [10]. This overview revealed that TTX fatality rates vary between $16.7 \%$ in Middle Eastern and North African countries and 21.4\% in European countries, both constituting $\sim 38 \%$ of the world's TTX-related fatalities. Furthermore, the highest numbers of cases have been noted for the Southern and South-Eastern shores, namely in Middle Eastern and North African countries, where $89.5 \%$ of cases were non-fatal and $10.5 \%$ were fatal [10]. In the vicinity of the Suez Canal, it is obvious to record the Lessepsian species L. sceleratus, that has been recorded there more than 40 years ago [25], and which explains the high number of TTX-poisoning cases in the South-Eastern Mediterranean region [25,27,43,48]. All the mentioned poisoning incidents emphasize the role of $L$. sceleratus as an emerging issue related to food safety and public health in the Mediterranean region $[10,50]$.

In the present study, muscles and skin of L. sceleratus in Lebanese waters showed TTX concentrations lower than those measured in the same organs of specimens collected from other parts of the Mediterranean Sea (Cyprus, Greece, Spain and Turkey), as well as the Red Sea and the Indian Ocean (Table 2). However, TTX concentrations measured in the gonads and liver of fish species collected in this study are considered high (Table 2); primarily the gonads that present the highest TTX concentrations based on the findings in the available literature $(252.97 \mu \mathrm{g} / \mathrm{g}$ in the largest Fish 1; Figure 3). Results from this study demonstrate that internal fish organs are the most toxic ones, in agreement with previous studies on L. sceleratus [2,11,51-53]. Moreover, toxicity levels in different fish organs reported in this paper are in line with the ones noted in published studies obtained via diverse methods of analyses (Table 2), as the highest TTX concentrations were found in gonads (mainly ovaries) and liver, followed by muscles and skin. Nonetheless, the toxicity content in muscles reported in this study was much lower than in other ones $(<0.7 \mu \mathrm{g} / \mathrm{g})$, while still exceeding the safety level $0.044 \mu \mathrm{g} / \mathrm{g}$ [6]. This TTX distribution through organs is attributed to the diet of pufferfish that eats food containing this toxin which goes initially 
to the liver, then to the skin/gonads and other organs, but also to the prolonged degradation of TTX in gonads [7,54]. The median lethal dose (LD50) concentrations for TTX in mammals are $0.01-0.014 \mu \mathrm{g} / \mathrm{g}$ for subcutaneous and $0.002-0.01 \mu \mathrm{g} / \mathrm{g}$ for intravenous administration $[55,56]$. In the present study, the majority of analyzed organs of the three investigated fish specimens show that TTX concentrations exceed the minimum acute dose of TTX for humans (wt. $50 \mathrm{~kg}$; $0.2 \mathrm{mg}$; Figure 3), which is a dose that causes adverse health effects [57]. Therefore, the present study, which is in harmony with the above-mentioned ones, clearly shows that L. sceleratus, purchased from the seafood market of Lebanon, is a toxic fish species and that even small individuals are not safe for consumption, since all the measured values of TTX in all the analyzed fish organs were above the safety level.

Table 2. TTX concentrations ( $\mu \mathrm{g} / \mathrm{g}$ ) in muscle, gonads, liver and skin of L. sceleratus from different studies, including the present one (in bold).

\begin{tabular}{|c|c|c|c|c|c|c|c|}
\hline & & Region & Muscle & Gonads & Liver & Skin & Method \\
\hline \multirow{9}{*}{$\begin{array}{c}\text { Mediterranean } \\
\text { Sea }\end{array}$} & [11] & $\begin{array}{l}\text { Rhodes Island, } \\
\text { Greece }\end{array}$ & $<1.10-10.1$ & $17.05-239$ & $16.12-88$ & $<1.10-6.63$ & MBA \\
\hline & [12] & $\begin{array}{l}\text { Rhodes Island, } \\
\text { Greece }\end{array}$ & $<\mathrm{LOQ}-3.47$ & $0.47-46.3$ & $4.20-44.2$ & $<\mathrm{LOQ}-1.40$ & LC-ESI-CID-MS/MS \\
\hline & [4] & $\begin{array}{l}\text { Mersin Bay, } \\
\text { Turkey }\end{array}$ & ND-2.83 & $0.43-52.1$ & ND-46.2 & $0.13-3.43$ & MBA \& LC-MS/MS \\
\hline & [14] & $\begin{array}{l}\text { Marmaris } \\
\text { and } \\
\text { Iskenderun } \\
\text { Bay, Turkey }\end{array}$ & $0.10-3.42$ & $0.17-80.0$ & $0.12-25.4$ & $0.10-3.30$ & LC-MS/MS \\
\hline & [13] & Spain & $0.7-0.9$ & $20.0-21.1$ & $2.3-4.6$ & $1.2-1.8$ & $\begin{array}{c}\text { LC-MS/MS \& } \\
\text { LCHRMS }\end{array}$ \\
\hline & [5] & $\begin{array}{l}\text { Mersin Bay, } \\
\text { Turkey }\end{array}$ & $0.70-5.12$ & $0.69-35.6$ & $0.89-21.1$ & $2.20-11.8$ & Q-TOF LC/MS \\
\hline & [58] & $\begin{array}{c}\text { Chrousou Bay, } \\
\text { Greece }\end{array}$ & $0.48-2.88$ & - & $0.73-10.83$ * & $1.19-3.17$ & $\begin{array}{c}\text { Electrochemical } \\
\text { MB-based } \\
\text { immunosensing tool, } \\
\text { LC-HRMS and mELISA }\end{array}$ \\
\hline & [7] & $\begin{array}{l}\text { Northern } \\
\text { Cyprus }\end{array}$ & $0.21-8.32$ & $0.32-12.87$ & $0.11-13.48$ & $0.16-6.54$ & dcELISA \\
\hline & Present study & $\begin{array}{c}\text { Tripoli, } \\
\text { Lebanon }\end{array}$ & $0.10-0.59$ & $0.26-252.97$ & $1.37-46.67$ & $0.15-0.70$ & LC-MS/MS \\
\hline Red Sea & [51] & Suez, Egypt & ND-27.9 & ND-165 & ND-54.1 & ND-26.2 & $\begin{array}{c}\text { TLC and } \\
\text { electrophoresis }\end{array}$ \\
\hline \multirow{3}{*}{ Indian Ocean } & [3] & Malaysia & 1.71 & - & - & - & GC-MS \\
\hline & [38] & Reunion Island & 5 & - & 17 & - & MBA \\
\hline & [59] & Malaysia & 30 & - & 24.7 & 0.51 & LC-MS/MS \\
\hline
\end{tabular}

Our results demonstrate the potential toxicity of $L$. sceleratus when consumed, since a couple of accidental intoxication cases related to its consumption were recently reported in Lebanon $[29,49]$. One of the straightforward reports related to TTX-poisoning in Lebanon describes the effects noted after the consumption of $L$. sceleratus gonads by a Lebanese man who entered a deep non-reactive reversible coma with the absence of brainstem reflexes within 3 to $4 \mathrm{~h}$ [29]. The symptoms started with perioral tingling, followed by dysarthria, after which the patient became quadriparetic, then developed respiratory and hemodynamic failure. The patient started to improve after $20 \mathrm{~h}$ and recovered his neurological baseline within $36 \mathrm{~h}$. All these symptoms have been attributed to TTX that blocked voltage-gated sodium channels and inhibited the production and propagation of action potentials [29]. Such incidents could be occurring because L. sceleratus juveniles are considered to be non-toxic and small individuals can be mistaken for some other edible fish species [58]. Moreover, the catch of the two Tetraodontidae toxic species, Lagocephalus 
sceleratus and Torquigener flavimaculosus, in purse seine fisheries in Lebanon were recently reported for the first time. Such new findings highlight the existence of a danger to consumers via accidental poisoning [60], as the presence of these toxic species in fish assemblages increases the potential of intoxication incidences among the consumers who eat small pelagic fish, as they do not distinguish small-juvenile fish species and traditionally eat them without the evisceration $[1,60]$, with their internal organs bearing TTX levels above the LDL0 and MAD (Table 2). This reflects a significant TTX-related risk on consumers, since the treatment is only symptomatic and mostly aggressive with a mortality rate around $60 \%$ [61].

Results in this study also demonstrate the relationship between the high toxicity of L. sceleratus and the size of fish-the bigger the fish the more toxic it is, which is in agreement with results found in other studies [11]. Although the organ distribution of toxins is reported to be species-specific [62], the geographic location and seasonal variation may influence the toxicity levels as the ecological food chain, the accumulation of the TTX-producer bacteria, local variations of toxicity, and the toxin composition in fish may vary in function of habitats and seasons [2,3,12,51,63-65].

Interesting results in the present study were embodied by the high concentrations of TTX in ovaries (female gonads of Fish 1 and 3) compared to the concentrations measured in testis (male gonads of Fish 2). The same pattern of gonads' toxicity was also noted in other studies on L. sceleratus [5], as well as on Lagocephalus lunaris and Chelonodon patoca where muscles and/or testis were non or weakly toxic [2]. Similar findings have been noted for fish from Cyprus by Akbora et al. [7] who mentioned that in winter, spring, and summer seasons females had higher toxicity levels than males.

The prolongation of this study throughout all the seasons would be interesting to evaluate the seasonal toxicity fluctuations in L. sceleratus invading the Lebanese waters, as well as the influence of fish gender on TTX levels.

\subsection{Expansion of L. sceleratus}

L. sceleratus is not limited to the Eastern Mediterranean Sea anymore, as it has been recorded in the Northern and Southern realms of the Western Mediterranean [66-74], as well as in the westernmost end of the Strait of Gibraltar at San Amaro beach, Spain, which opens the possibility for this Indo-Pacific invasive species to spread beyond the Mediterranean Sea, risking the future expansion of Lessepsian bioinvasions to the Atlantic Ocean [75]. Moreover, the undergoing ecological change attributed to global warming and other climate change-related consequences can be a potential reason behind the expansion of invasive species, such as L. sceleratus in the Mediterranean Sea [11,12,76] and pp. 328-374 in [76]. However, more scientific research and risk assessments with regards to its toxicity and other potential public health concerns have to be undertaken.

\subsection{Regulations}

All the above-mentioned findings highlight the need for a new risk-based approach to control TTX-caused food safety issues, but also considering that to this date a maximum permitted TTX concentration in seafood has not been established by the European legislation [6]. Currently, EU regulation only manages the risk by prohibiting the marketing of fishery products obtained from fish of the Tetraodontidae families, Molidae, Diodontidae and Canthigasteridae [41], thus not yet considering other marine product categories that could potentially carry TTX [10]. Moreover, in order to efficiently and rapidly avoid TTXrelated intoxications, the availability of low-cost and user-friendly tools for TTXs detection will contribute to guarantee seafood safety [58]. All these regulations and new techniques should be implemented as soon as possible since once L. sceleratus, or other TTX-bearers and invasive species, manage to establish stable populations in a new environment, they can hardly be eradicated and therefore urgent action in the form of control of spread and removal are very important, as these are often the only effective methods in combating their harmful effects [15]. 
In Lebanon, after a couple of human intoxications due to pufferfish consumption, the Ministry of Agriculture (responsible for fisheries) issued a decision (No. 676/1 of 27 July 2011) that prohibits the catchment, transportation, selling, and the consumption of both Lagocephalus sp. and Torquigener sp.

\section{Conclusions}

In this study, morphologically different individuals of L. sceleratus collected from the Lebanese waters were analyzed for TTX and its analogue 4,9-anhydro TTX concentrations. The obtained results demonstrated that TTX concentrations varied between 0.10 and $252.97 \mu \mathrm{g} / \mathrm{g}$, where internal fish organs were the most toxic ones with TTX showing the highest concentrations in gonads (mainly ovaries) and liver, followed by muscles and skin where measured toxicity always exceeded the safety level $(0.044 \mu \mathrm{g} / \mathrm{g})$ [6]. Another remarkable result was the high concentrations of TTX found in ovaries compared to the ones measured in testis, showing a potential relationship between the toxicity and the gender of fish. Moreover, this paper warns of the toxicity of L. sceleratus, and gives insights on its expansion and its ecological and economic effects. Finally, this paper offers a few recommendations to insist on the importance of implementing systematic monitoring of already-known and emerging TTX-bearing organisms in order to avoid any potential human intoxication and to control the expansion of this invasive species.

\section{Materials and Methods}

\subsection{Samples Collection and Preparation}

Three specimens of pufferfish Lagocephalus sceleratus (Gmelin, 1789) were bought from a local fisherman directly after collection by a gillnet offshore Tripoli city, North Lebanon (Figure 4), in February 2020 (winter), and frozen at $-20{ }^{\circ} \mathrm{C}$ for one night. Morphological and sex determination assessments of each individual were conducted in order to obtain information on their total length, weight, sex, and maturity. The total length (TL), to the nearest millimeter and total weight (TW), to the nearest $0.01 \mathrm{~g}$ of the fish were recorded for each specimen. Sexual maturity was determined using the instruction manual for the MEDITS survey 6 [77]. Each individual was partially thawed in order to avoid toxin cross-contamination between tissues or organs, and subsequently dissected into muscles, liver, skin, and gonads. After species identification, dissection, and morphological measurements, each organ of the fish was weighed, then frozen and transported to the Institute of Oceanography and fisheries in Split (Croatia) for TTX analysis via LC-MS/MS.

\subsection{Sample Extraction}

Three individual fish specimens were dissected and $2 \mathrm{~g}$ of each of the following organs were weighed: muscle, liver, gonads, and skin. Extraction started by adding $7.5 \mathrm{~mL}$ of $1 \%$ acetic acid to polypropylene test tube containing each fish tissue that was homogenized at $2400 \mathrm{rpm}$ for $10 \mathrm{~min}$ on Ultra-turrax homogenizer (Cole-Parmer, GEN 700, Vernon Hills, IL, USA), then placed in an ultrasonic water bath for $10 \mathrm{~min}$ at $35 \mathrm{kHz}$ (DT $100 \mathrm{H}$, Bandelin sonorex digitec, Germany) followed by a boiling water bath $\left(100{ }^{\circ} \mathrm{C}\right)$ for $10 \mathrm{~min}$. After cooling to room temperature $\left(25^{\circ} \mathrm{C}\right)$ and volume adjusted to $7.5 \mathrm{~mL}$ by adding deionized water, the extracts were centrifuged at $3000 \times \mathrm{g}$ for $20 \mathrm{~min}$ at $4{ }^{\circ} \mathrm{C}$ (Hettich Zentrifugen, Rotina 420, Germany) and the supernatants were filtered through $0.2 \mu$ m nylon syringe filters and poured directly in autosampler glass $2 \mathrm{~mL}$ vials for LC-MS/MS analysis.

The Certified Reference Materials (Cifga laboratorio, Lugo, Spain) contained the following concentrations of TTX and its analogue: $25.9 \pm 1.3 \mu \mathrm{g} / \mathrm{g}$ TTX and $2.99 \pm 0.16 \mu \mathrm{g} / \mathrm{g}$ 4,9-anhydro TTX. 

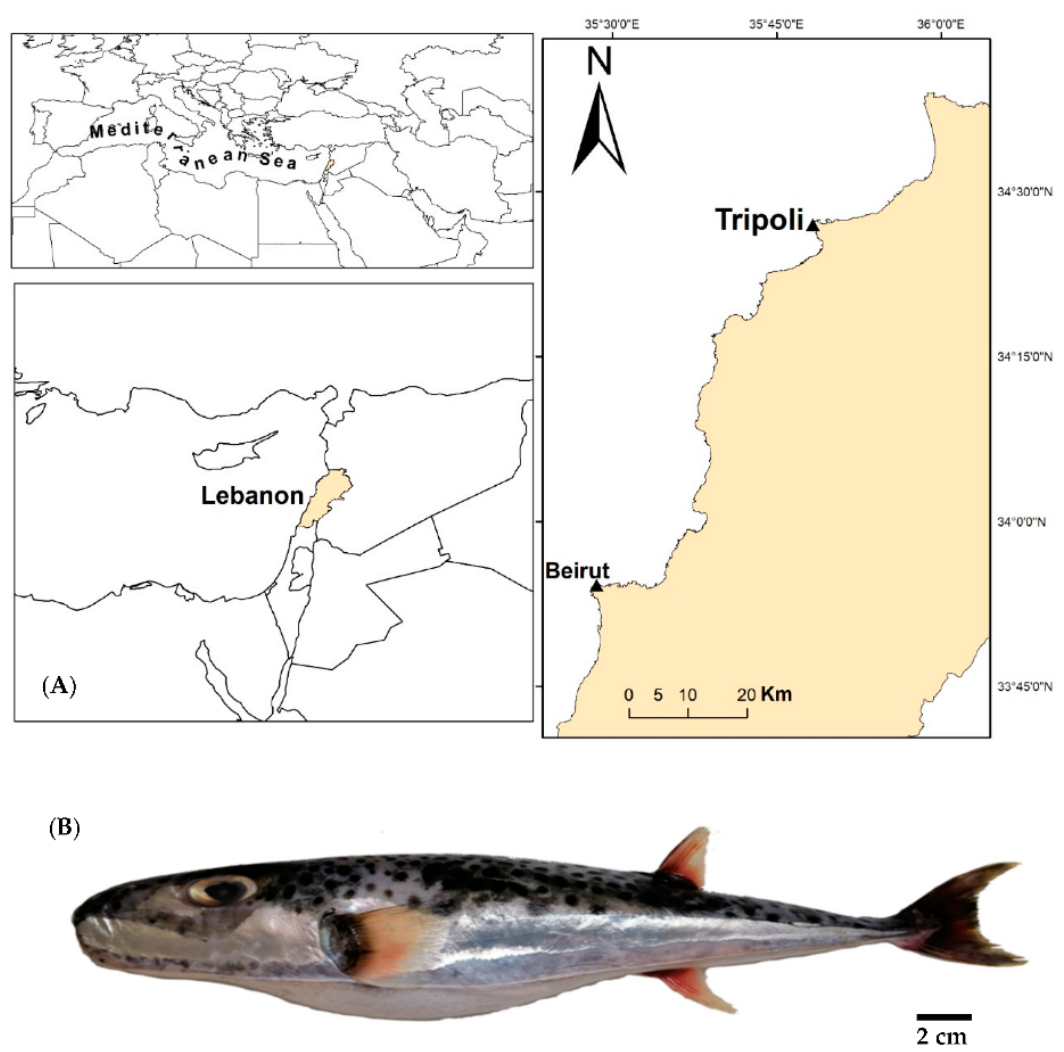

Figure 4. (A) Sample collection area; (B) a photo of Lagocephalus sceleratus@ Sharif Jemaa, CNRS-L.

In order to quantitatively determine TTX concentrations, a highly sensitive analytical method was employed using the Agilent mass spectrometer operated in positive ion mode via electrospray ionization (ESI). An Agilent Technologies LC-MS/MS analytical system coupled with Triple Quad 6410, Degasser 1200, Quaternary Pump 1200, Auto Sampler 1290 and Thermostatted Column Compartment 1290 was used, while the LC system was equipped with a Poroshell 120 EC-C18 column $(2.1 \times 50 \mathrm{~mm}, 2.7 \mu \mathrm{m})$ and Poroshell 120 EC-C18 Guard precolumn $(2.1 \times 5 \mathrm{~mm}, 2.7 \mu \mathrm{m})$. Water $(35 \%)$ and $95 \%$ acetonitrile (65\%), both containing $2 \mathrm{mM}$ ammonium formate and $50 \mathrm{mM}$ formic acid were the mobile phase solvents; the flow rate was set to $0.3 \mathrm{~mL} / \mathrm{min}$ and the column temperature to $25^{\circ} \mathrm{C}$. Standard solution of TTX and 4,9-anhydro TTX was used to optimize the MS parameters, including the molecular ion peak $(\mathrm{M}+\mathrm{H})+$ occurring at $\mathrm{m} / \mathrm{z} 319.8$, which showed the molecular weight for TTX (319.1), and the molecular ion peak $(\mathrm{M}+\mathrm{H})+$ occurring at $\mathrm{m} / \mathrm{z}$ 302.1, which showed the molecular weight for 4,9-anydro TTX (302.2). Two product ions were analyzed in the spectrometer and the transitions were $\mathrm{m} / \mathrm{z} 319.8 / 302.0 \mathrm{and} \mathrm{m} / \mathrm{z}$ 319.8/161.9 for TTX and 302.1/256.0 and 302.1/162.0 for 4,9-anhydro TTX.

Standard calibration curves were obtained by using an externally certified reference solution (Cifga laboratorio, Lugo, Spain) prepared in six different concentrations for TTX $(20.0,50.0,100.0,200.0,500.0$, and $1000.0 \mathrm{ng} / \mathrm{mL})$ and for 4,9-anhydro TTX $(2.37,5.94$, $11.87,29.76,59.63$, and $118.73 \mathrm{ng} / \mathrm{mL}$ ), all measured in triplicate. The detection limits of $1.43 \mathrm{ng} / \mathrm{mL}$ and $2.10 \mathrm{ng} / \mathrm{mL}$ for TTX and 4,9-anhydro TTX, respectively, were obtained from three Standard Deviations (SD) of seven measurements of the lowest standard, while the limits of quantification of $4.77 \mathrm{ng} / \mathrm{mL}$ for TTX and $7.01 \mathrm{ng} / \mathrm{mL}$ for 4,9-anhydro TTX were obtained from 10 SD of seven measurements of the lowest standard (see supplementary document to check the calibration plots). 


\begin{abstract}
Supplementary Materials: The following supporting information can be downloaded at: https: / / www.mdpi.com/article/10.3390/toxins14020123/s1, Supplementary Figure S1: Total ion current plots of LC-MS/MS derived by the multiple reaction monitoring (MRM) of (a) TTX standard calibration solution (Retention Time $=0.8 \mathrm{~min}$ ) and Lagocephalus sceleratus tissue extracts of: $(\mathrm{b})$ skin, (c) muscle, (d) liver and (e) gonad, sampled at the South-Eastern Mediterranean Sea, Lebanon. Supplementary Figure S2: Response of the instrument and concentrations of standard solutions are linear, $\mathrm{r}^{2}>0.99$, as shown for TTX. Supplementary Figure S3: Response of the instrument and concentrations of standard solutions are linear, $\mathrm{r}^{2}>0.99$, as shown for 4,9-anhydro TTX.
\end{abstract}

Author Contributions: Conceptualization, A.E.R.H. and I.U.; methodology, A.E.R.H., I.U., S.J. and N.N.; validation, I.U. and R.R.-B.; formal analysis, A.E.R.H. and I.U.; data curation, I.U.; writingoriginal draft preparation, A.E.R.H.; writing—review and editing, A.E.R.H., I.U., R.R.-B., M.F., C.M., S.J. and N.N.; funding acquisition, M.F., A.E.R.H., C.M. and S.J. All authors have read and agreed to the published version of the manuscript.

Funding: This study was supported through the EU-funded project ELME (Evaluation of the Lebanese Marine Environment: a multidisciplinary study)/Reference number: ENI/2018/398-295. The study was funded by the Ministry of Science and Education of the Republic of Croatia as a part of Multiannual Financing intended for institutions.

Data Availability Statement: Data can be shared upon request.

Acknowledgments: The authors would like to thank Salim KABBARA and Houssein Jaber for their assistance during the sampling and preparation of fish samples, and Mohammad Merheb for drawing the map.

Conflicts of Interest: The authors declare no conflict of interest. The funders had no role in the design of the study; in the collection, analyses, or interpretation of data; in the writing of the manuscript, or in the decision to publish the results.

\title{
References
}

1. Hassoun, A.E.R.; Ujević, I.; Mahfouz, C.; Fakhri, M.; Roje-Busatto, R.; Jemaa, S.; Nazlić, N. Occurrence of domoic acid and cyclic imines in marine biota from Lebanon-Eastern Mediterranean Sea. Sci. Total Environ. 2021, 755, 142542. [CrossRef] [PubMed]

2. Noguchi, T.; Arakawa, O.; Takatani, T. TTX accumulation in pufferfish. Comp. Biochem. Physiol. Part D Genom. Proteom. 2006, 1, 145-152. [CrossRef] [PubMed]

3. Nin Man, C.; Noor, N.M.; Harn, G.L.; Lajis, R.; Mohamad, S. Screening of tetrodotoxin in puffers using gas chromatography-mass spectrometry. J. Chromatogr. A 2010, 1217, 7455-7459. [CrossRef] [PubMed]

4. Kosker, A.R.; Özogul, F.; Durmus, M.; Ucar, Y.; Ayas, D.; Regenstein, J.M.; Özogul, Y. Tetrodotoxin levels in pufferfish (Lagocephalus sceleratus) caught in the Northeastern Mediterranean Sea. Food Chem. 2016, 210, 332-337. [CrossRef] [PubMed]

5. Kosker, A.R.; Özogul, F.; Ayas, D.; Durmus, M.; Ucar, Y.; Regenstein, J.M.; Özogul, Y. Tetrodotoxin levels of three pufferfish species (Lagocephalus sp.) caught in the North-Eastern Mediterranean sea. Chemosphere 2019, 219, 95-99. [CrossRef]

6. EFSA CONTAM Panel (EFSA Panel on Contaminants in the Food Chain); Knutsen, H.K.; Barregärd, A.J.; Bignami, L.; Brüschweiler, M.; Ceccatelli, B.; Cottrill, S.; Dinovi, B.; Edler, M.; Grasl-Kraupp, L.; et al. Scientific Opinion on the Risks for Public Health Related to the Presence of Tetrodotoxin (TTX) and TTX Analogues in Marine Bivalves and Gastropods. EFSA J. 2017, 15, e04752.

7. Akbora, H.D.; Kunter, I.; Erçetin, T.; Elagöz, A.M.; Çiçek, B.A. Determination of tetrodotoxin (TTX) levels in various tissues of the silver cheeked puffer fish (Lagocephalus sceleratus (Gmelin, 1789)) in Northern Cyprus Sea (Eastern Mediterranean). Toxicon 2020, 175, 1-6. [CrossRef]

8. Madejska, A.; Michalski, M.; Osek, J. Marine tetrodotoxin as a risk for human health. J. Vet. Res. 2019, 63, 579-586. [CrossRef]

9. Miyazawa, K.; Noguchi, T. Distribution and origin of tetrodotoxin. J. Toxicol. Toxin Rev. 2001, 20, 11-33. [CrossRef]

10. Guardone, L.; Maneschi, A.; Meucci, V.; Gasperetti, L.; Nucera, D.; Armani, A. A Global Retrospective Study on Human Cases of Tetrodotoxin (TTX) Poisoning after Seafood Consumption. Food Rev. Int. 2020, 36, 645-667. [CrossRef]

11. Katikou, P.; Georgantelis, D.; Sinouris, N.; Petsi, A.; Fotaras, T. First report on toxicity assessment of the Lessepsian migrant pufferfish Lagocephalus sceleratus (Gmelin, 1789) from European waters (Aegean Sea, Greece). Toxicon 2009, 54, 50-55. [CrossRef] [PubMed]

12. Rodríguez, P.; Alfonso, A.; Otero, P.; Katikou, P.; Georgantelis, D.; Botana, L.M. Liquid chromatography-mass spectrometry method to detect Tetrodotoxin and Its analogues in the puffer fish Lagocephalus sceleratus (Gmelin, 1789) from European waters. Food Chem. 2012, 132, 1103-1111. [CrossRef]

13. Rambla-Alegre, M.; Reverté, L.; del Río, V.; de la Iglesia, P.; Palacios, O.; Flores, C.; Caixach, J.; Campbell, K.; Elliott, C.T.; Izquierdo-Muñoz, A.; et al. Evaluation of tetrodotoxins in puffer fish caught along the Mediterranean coast of Spain. Toxin profile of Lagocephalus sceleratus. Environ. Res. 2017, 158, 1-6. [CrossRef] [PubMed] 
14. Acar, C.; Ishizaki, S.; Nagashima, Y. Toxicity of the Lessepsian pufferfish Lagocephalus sceleratus from eastern Mediterranean coasts of Turkey and species identification by rapid PCR amplification. Eur. Food Res. Technol. 2017, 243, 49-57. [CrossRef]

15. Ujević, I.; Roje-Busatto, R.; Dragičević, B.; Dulčić, J. Tetrodotoxin in Invasive Silver-cheeked Toadfish Lagocephalus sceleratus (Gmelin, 1789) in the Adriatic Sea. In The Handbook of Environmental Chemistry; Springer: Singapore, 2020; pp. $141-149$.

16. Por, F.D. The Suez Canal. In Lessepsian Migration; Springer: Berlin/Heidelberg, Germany, 1978; pp. 39-86.

17. Spanier, E.; Galil, B.S. Lessepsian migration: A continuous biogeographical process. Endeavour 1991, 15, 102-106. [CrossRef]

18. Galil, B.S.; Zenetos, A. A sea change-Exotics in the Eastern Mediterranean Sea. In Invasive Aquatic Species of Europe. Distribution, Impacts and Management; Springer: Dordrecht, The Netherlands, 2013; pp. 325-336.

19. Zenetos, A.; Gofas, S.; Morri, C.; Rosso, A.; Violanti, D.; García Raso, J.E.; Cinar, M.E.; Almogi-Labin, A.; Ates, A.S.; Azzurro, E.; et al. Alien species in the Mediterranean Sea by 2012. A contribution to the application of European Union's Marine Strategy Framework Directive (MSFD). Part 2. Introduction trends and pathways. Mediterr. Mar. Sci. 2012, 13, 328-352. [CrossRef]

20. Otero, M.; Cebrian, E.; Francour, P.; Galil, B.; Savini, D. Monitoring Marine Invasive Species in Mediterranean Marine Protected Areas (MPAs): A Strategy and Practical Guide for Managers; IUCN: Malaga, Spain, 2013; p. 136.

21. Yaglioglu, D.; Turan, C.; Erguden, D.; Gurlek, M. Range expansion of silverstripe blaasop, Lagocephalus sceleratus (Gmelin, 1789), to the northeastern Mediterranean Sea. Biharean Biol. 2011, 5, 159-161.

22. Ulman, A.; Çiçek, B.A.; Salihoglu, I.; Petrou, A.; Patsalidou, M.; Pauly, D.; Zeller, D. Unifying the catch data of a divided island: Cyprus's marine fisheries catches, 1950-2010. Environ. Dev. Sustain. 2015, 17, 801-821. [CrossRef]

23. Golani, D.; Öztürk, B.; Başusta, N. Fishes of the Eastern Mediterranean-Turkish Marine Research Foundation (Publication No. 24). Istanb. Turk. 2006, 59, 121.

24. Akyol, O.; Ünal, V.; Ceyhan, T.; Bilecenoglu, M. First confirmed record of Lagocephalus sceleratus(Gmelin, 1789) in the Mediterranean Sea. J. Fish Biol. 2005, 66, 1183-1186. [CrossRef]

25. Mouneimne, N. Liste des poissons de la côte du Liban (Méditerranée orientale). Cybium 1977, 1, 37-66.

26. Golani, D.; Levy, Y. New records and rare occurrences of fish species from the Mediterranean coast of Israel. Zool. Middle East 2005, 36, 27-32. [CrossRef]

27. Rabou, A.F.N.A. On the occurrence and health risks of the Silver-cheeked Toadfish (Lagocephalus sceleratus Gmelin, 1789) in the marine ecosystem of the Gaza Strip, Palestine. Biodiversitas J. Biol. Divers. 2019, 20, 2618-2625. [CrossRef]

28. Deidun, A.; Fenech-Farrugia, A.; Castriota, L.; Falautano, M.; Azzurro, E.; Andaloro, F. First record of the silver-cheeked toadfish Lagocephalus sceleratus (Gmelin, 1789) from Malta. BioInvasions Rec. 2015, 4, 139-142. [CrossRef]

29. Awada, A.; Chalhoub, V.; Awada, L.; Yazbeck, P. Coma profond aréactif réversible après intoxication par des abats d'un poisson méditerranéen. Rev. Neurol. 2010, 166, 337-340. [CrossRef] [PubMed]

30. Chopra, S.A. A case of fatal puffer-fish poisoning in a Zanzibari fisherman. East Afr. Med. J. 1967, 44, 493-496. [PubMed]

31. Laobhripatr, S.; Limpakarnjanarat, K.; Sangwonloy, O.; Sudhasaneya, S.; Anuchatvorakul, B.; Leelasitorn, S.; Saitanu, K. Food poisoning due to consumption of the freshwater puffer Tetraodon fangi in Thailand. Toxicon 1990, 28, 1372-1375. [CrossRef]

32. Mahmud, Y.; Arakawa, O.; Noguchi, T. An epidemic survey on freshwater puffer poisoning in Bangladesh. J. Nat. Toxins 2000, 9 , 319-326. [PubMed]

33. Ravaonindrina, N.; Andriamaso, T.H.; Rasolofonirina, N. Intoxication après consommation de poisson globe à Madagascar: À propos de 4 cas. Arch. Inst. Pasteur Madag 2001, 67, 61-64.

34. Ahasan, H.A.; Mamun, A.A.; Karim, S.R.; Bakar, M.A.; Gazi, E.A.; Bala, C.S. Paralytic complications of puffer fish (tetrodotoxin) poisoning. Singap. Med. J. 2004, 45, 73-74.

35. Chowdhury, F.R.; Ahasan, H.A.M.N.; Al Mamun, A.; Rashid, A.K.M.M.; Al Mahboob, A. Puffer fish (Tetrodotoxin) poisoning: An analysis and outcome of six cases. Trop. Dr. 2007, 37, 263-264. [CrossRef] [PubMed]

36. Fernández-Ortega, J.F.; Santos, J.M.M.-D.L.; Herrera-Gutiérrez, M.E.; Fernández-Sánchez, V.; Loureo, P.R.; Rancaño, A.A.; Téllez-Andrade, A. Seafood Intoxication by Tetrodotoxin: First Case in Europe. J. Emerg. Med. 2010, 39, 612-617. [CrossRef] [PubMed]

37. Silva, C.C.P.; Zannin, M.; Rodrigues, D.S.; Dos Santos, C.R.; Correa, I.A.; Junior, V.H. Clinical and epidemiological study of 27 poisonings caused by ingesting puffer fish (Tetrodontidae) in the states of Santa Catarina and Bahia, Brazil. Rev. Inst. Med. Trop. São Paulo 2010, 52, 51-56. [CrossRef] [PubMed]

38. Puech, B.; Batsalle, B.; Roget, P.; Turquet, J.; Quod, J.-P.; Allyn, J.; Idoumbin, J.-P.; Chane-Ming, J.; Villefranque, J.; Mougin-Damour, K.; et al. Family tetrodotoxin poisoning in Reunion Island (Southwest Indian Ocean) following the consumption of Lagocephalus sceleratus (Pufferfish). Bull. Société Pathol. Exot. 2014, 107, 79-84. [CrossRef]

39. Ajani, P.; Harwood, D.T.; Murray, S.A. Recent Trends in Marine Phycotoxins from Australian Coastal Waters. Mar. Drugs 2017, 15, 33. [CrossRef] [PubMed]

40. Indumathi, S.; Khora, S. Toxicity assessment and screening of tetrodotoxin in the oblong blowfish (Takifugu oblongus) from the Tamil Nadu Coast of Bay of Bengal, India. Asian Pac. J. Trop. Med. 2017, 10, 278-284. [CrossRef]

41. Council, E.U. Regulation (EC) No 853/2004 of the European Parliament and of the Council of 29 April. Laying down Specific Hygiene Rules for on the Hygiene of Foodstuffs. Off. J. Eur. Union 2004, 139, 55-205.

42. REGULATION (EU) 2017/625 of the EuropeanParliament and of the Council of 15 March 2017. Available online: https: / / eur-lex.europa.eu/legal-content/EN/TXT/?uri=celex\%3A32017R0625 (accessed on 19 December 2021). 
43. Bentur, Y.; Ashkar, J.; Lurie, Y.; Levy, Y.; Azzam, Z.S.; Litmanovich, M.; Golik, M.; Gurevych, B.; Golani, D.; Eisenman, A. Lessepsian migration and tetrodotoxin poisoning due to Lagocephalus sceleratus in the eastern Mediterranean. Toxicon 2008, 52, 964-968. [CrossRef]

44. Field, J. Puffer fish poisoning. Emerg. Med. J. 1998, 15, 334-336. [CrossRef] [PubMed]

45. Noguchi, T.; Ebesu, J.S.M. Puffer poisoning: Epidemiology and treatment. J. Toxicol. Toxin Rev. 2001, 20, 1-10. [CrossRef]

46. Bilecenoglu, M.; Kaya, M.; Akalin, S. Range expansion of silverstripe blaasop, Lagocephalus sceleratus (Gmelin, 1789), to the northern Aegean Sea. Aquat. Invasions 2006, 1, 289-291. [CrossRef]

47. Isbister, G.K.; Son, J.; Ujma, J.; Smith, B.; Milder, D.G.; Wang, F.; MacLean, C.J.; Lin, C.S.; Kiernan, M.C.; Balit, C.R. Puffer fish poisoning: A potentially life-threatening condition. Med. J. Aust. 2002, 177, 650-653. [CrossRef] [PubMed]

48. Eisenman, A.; Rusetski, V.; Sharivker, D.; Yona, Z.; Golani, D. An odd pilgrim in the Holy Land. Am. J. Emerg. Med. 2008, 26, 383.e3-383.e6. [CrossRef] [PubMed]

49. Chamandi, S.C.; Kallab, K.; Mattar, H.; Nader, E. Human poisoning after ingestion of puffer fish caught from Mediterranean Sea. Middle East J. Anaesthesiol. 2009, 20, 19583080.

50. Streftaris, N.; Zenetos, A. Alien marine species in the Mediterranean-the 100 'Worst Invasives' and their impact. Mediterr. Mar. Sci. 2006, 7, 87-118. [CrossRef]

51. El-Sayed, M.; Yacout, G.A.; El-Samra, M.; Ali, A.; Kotb, S.M. Toxicity of the Red Sea pufferfish Pleuranacanthus sceleratus "El-Karad". Ecotoxicol. Environ. Saf. 2003, 56, 367-372. [CrossRef]

52. Kanoh, S.; Noguchi, T.; Kamimura, S.; Hashimoto, K. A Survey of Toxicity of the Pufferfish, Fugu pardalis Inhabiting the Sanriku Coast. J. Food Hyg. Soc. Jpn. 1984, 25, 24-29. [CrossRef]

53. Hoang, N.H. Research on Toxins in Toxic Marine Fish Species of VIETNAM. 2008. Available in the Webpage of the Research Institute for Marine Fisheries. Available online: http://rimf.org.vn/bantin/tapchi_newsdetail.asp?TapChiID \protect\$relax

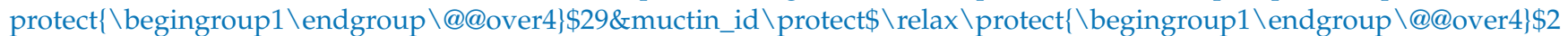
\&news_id \protect\$ $\backslash$ relax \protect $\backslash$ begingroup1 \endgroup $\backslash @ @ o v e r 4\} \$ 1673 \&$ lang $\backslash$ protect $\$ \backslash$ relax $\backslash$ protect $\{\backslash$ begingroup1 \endgroup \@@over4\}\$1 (accessed on 1 September 2019). (In Vietnamese)

54. Bane, V.; Lehane, M.; Dikshit, M.; O’Riordan, A.; Furey, A. Tetrodotoxin: Chemistry, Toxicity, Source, Distribution and Detection. Toxins 2014, 6, 693-755. [CrossRef] [PubMed]

55. Alcaraz, A.; Whipple, R.; Gregg, H.; Andresen, B.; Grant, P. Analysis of tetrodotoxin. Forensic Sci. Int. 1999, 99, 35-45. [CrossRef]

56. Nzoughet, J.K.; Campbell, K.; Barnes, P.; Cooper, K.; Chevallier, O.P.; Elliott, C.T. Comparison of sample preparation methods, validation of an UPLC-MS/MS procedure for the quantification of tetrodotoxin present in marine gastropods and analysis of pufferfish. Food Chem. 2013, 136, 1584-1589. [CrossRef] [PubMed]

57. Chan, T.Y.K. Epidemiology and Clinical Features of Ciguatera Fish Poisoning in Hong Kong. Toxins 2014, 6, 2989-2997. [CrossRef] [PubMed]

58. Leonardo, S.; Kiparissis, S.; Rambla-Alegre, M.; Almarza, S.; Roque, A.; Andree, K.B.; Christidis, A.; Flores, C.; Caixach, J.; Campbell, K.; et al. Detection of tetrodotoxins in juvenile pufferfish Lagocephalus sceleratus (Gmelin, 1789) from the North Aegean Sea (Greece) by an electrochemical magnetic bead-based immunosensing tool. Food Chem. 2019, 290, 255-262. [CrossRef] [PubMed]

59. Azman, A.M.N.; Samsur, M.; Othman, M. Distribution of tetrodotoxin among tissues of puffer fish from Sabah and Sarawak waters. Sains Malays. 2014, 43, 1003-1011.

60. Jemaa, S.; Lteif, M.; Fakhri, M.; Khalaf, G. The Biodiversity of Pelagic Fish Caught by Purse Seines in Tripoli, northern Lebanese Coast. Leban. Sci. J. 2021, in press.

61. Lange, W.R. Puffer fish poisoning. Am. Fam. Physician 1990, 42, 1029-1033.

62. Noguchi, T.; Arakawa, O. Tetrodotoxin-Distribution and Accumulation in Aquatic Organisms, and Cases of Human Intoxication. Mar. Drugs 2008, 6, 220-242. [CrossRef] [PubMed]

63. Yu, C.-F.; Yu, P.H.-F. The annual toxicological profiles of two common puffer fish, Takifugu niphobles (Jordan and Snyder) and Takifugu alboplumbeus (Richardson), collected along Hong Kong coastal waters. Toxicon 2002, 40, 313-316. [CrossRef]

64. Jen, H.-C.; Lin, S.-J.; Tsai, Y.-H.; Chen, C.-H.; Lin, Z.-C.; Hwang, D.-F. Tetrodotoxin poisoning evidenced by solid-phase extraction combining with liquid chromatography-tandem mass spectrometry. J. Chromatogr. B 2008, 871, 95-100. [CrossRef]

65. Campbell, S.; Harada, R.; DeFelice, S.; Bienfang, P.; Li, Q. Bacterial production of tetrodotoxin in the pufferfish Arothron hispidus. Nat. Prod. Res. 2009, 23, 1630-1640. [CrossRef] [PubMed]

66. Jribi, I.; Bradai, M. First record of the Lessepsian migrant species Lagocephalus sceleratus (Gmelin, 1789) (Actinopterygii: Tetraodontidae) in the Central Mediterranean. BioInvasions Rec. 2012, 1, 49-52. [CrossRef]

67. Milazzo, M.; Azzurro, E.; Badalamenti, F. On the occurrence of the silverstripe blaasop Lagocephalus sceleratus (Gmelin, 1789) along the Libyan coast. BioInvasions Rec. 2012, 1, 125-127. [CrossRef]

68. Ben Souissi, J.; Rifi, M.; Ghanem, R.; Ghozzi, L.; Boughedir, W.; Azzurro, E. Lagocephalus sceleratus (Gmelin, 1789) expands through the African coasts towards the Western Mediterranean Sea: A call for awareness. Manag. Biol. Invasions 2014, 5, 357-362. [CrossRef]

69. Azzurro, E.; Tuset, V.; Lombarte, A.; Maynou, F.; Simberloff, D.; Rodríguez-Pérez, A.; Solé, R.V. External morphology explains the success of biological invasions. Ecol. Lett. 2014, 17, 1455-1463. [CrossRef] [PubMed] 
70. Tiralongo, F.; Tibullo, D. Lagocephalus sceleratus (Gmelin, 1789),(Pisces: Tetraodontidae) reaches the Italian Ionian Sea. Kapiris et al. (2014) New Mediterr. Mar. Biodivers. Rec. Mediterr. Mar. Sci. 2014, 15, 198-212.

71. Kara, M.H.; Ben Lamine, E.; Francour, P. Range expansion of an invasive pufferfish, Lagocephalus sceleratus (Actinopterygii: Tetraodontiformes: Tetraodontidae), to the south-western mediterranean. Acta Ichthyol. Piscat. 2015, 45, 103-108. [CrossRef]

72. Andaloro, F.; Castriota, L.; Falautano, M.; Azzurro, E.; Deidun, A.; Fenech-Farrugia, A. Public feedback on early warning initiatives undertaken for hazardous non-indigenous species: The case of Lagocephalus sceleratus from Italian and Maltese waters. Manag. Biol. Invasions 2016, 7, 313-319. [CrossRef]

73. Akyol, O.; Ünal, V. Long journey of Lagocephalus sceleratus (Gmelin, 1789) throughout the Mediterranean Sea. Nat. Eng. Sci. 2017, 2, 41-47. [CrossRef]

74. Coro, G.; Vilas, L.G.; Magliozzi, C.; Ellenbroek, A.; Scarponi, P.; Pagano, P. Forecasting the ongoing invasion of Lagocephalus sceleratus in the Mediterranean Sea. Ecol. Model. 2018, 371, 37-49. [CrossRef]

75. Azzurro, E.; Bariche, M. The long reach of the Suez Canal: Lagocephalus sceleratus (Gmelin, 1789) an unwanted Indo-Pacific pest at the Atlantic gate. BioInvasions Rec. 2020, 9, 204-208. [CrossRef]

76. Balzan, M.V.; Hassoun, A.E.R.; Aroua, N.; Baldy, V.; Bou Dagher, M.; Branquinho, C.; Dutay, J.-C.; El Bour, M.; Médail, F.; Mojtahid, M.; et al. Ecosystems. In Climate and Environmental Change in the Mediterranean Basin-Current Situation and Risks for the Future. First Mediterranean Assessment Report; Cramer, W., Guiot, J., Marini, K., Eds.; Union for the Mediterranean, Plan Bleu, UNEP/MAP: Marseille, France, 2020; pp. 323-468, ISBN 9782957741601. [CrossRef]

77. MEDITS Working Group. MEDITS-Handbook. Revision n. 6; 2012; 92p. Available online: https://www.sibm.it/MEDITS\%202011 /docs / Medits-Handbook-2012\%20versione\%20definitiva.pdf (accessed on 19 December 2021). 